\title{
Studies on Length-weight and Length-length Relationships, Relative Condition Factor and Fulton's Condition Factor of Hemiculter leucisculus (Pisces: Cyprinidae) from the Southwestern Caspian Sea Basin
}

\author{
H. Mousavi-Sabet ${ }^{*}$ A. Habibi and O. Bagherpur \\ Department of Fisheries Sciences, Faculty of Natural Resources, University of Guilan, \\ Sowmeh Sara, Guilan, Iran \\ EE-mail:mosavii.h@gmail.com /mousavi-sabet@guilan.ac.ir
}

Received: 03.04.2013, Accepted: 11.06.2013

\begin{abstract}
In this study, length-weight (LWR) and length-length relationships (LLRs), relative condition factor $\left(\mathrm{k}_{\mathrm{rel}}\right)$ and Fulton's condition factor $(\mathrm{k})$ of 235 Hemiculter leucisculus Basilewsky were determined between the periods of March 2012 to February 2013 in Sefidroud River, in the Southwestern Caspian Sea basin. The maximum recorded total length for males and females were $16.90 \mathrm{~cm}$ and $18.10 \mathrm{~cm}$, respectively. The length-length relationships among the total length (TL), fork length (FL) and standard length (SL) for $H$. leucisculus were found to be highly significant $\left(\mathrm{r}^{2}>0.968, \mathrm{p}<0.001\right)$. The length-weight relationship shows the obtained $b$ values for males, females and male-females were $2.549,2.680$ and 2.465 respectively, which indicated a negative allometric growth trend of this species. Also, relative condition factor $\left(\mathrm{K}_{\mathrm{rel}}\right)$ for males, females and male-females were $0.710,0.622$ and 0.743 respectively and Fulton's condition factor $(\mathrm{K})$ for males, females and malefemales were $0.922,0.842$ and 0.843 respectively. These results will be useful for fishery managers to impose adequate regulations for sustainable fishery management.
\end{abstract}

Key words: Condition factor, Length-weight relationship, Sefidroud River, Iran

\section{Introduction}

$H$. leucisculus Basilewsky is a noneindigenous fish in the Caspian Sea basin. Its original distribution includes the rivers of China, Korea and Vietnam, and the Amur River basin (Holčík and Razavi, 1992). In Iran, H. leucisculus is reported from the International Wetlands includes Alma-Gol, Adji-Gol and Ala-Gol (Patimar et al., 2008) and from Zarivar Lake (Esmaeili et al., 2011). Also Abdoli (2000) recorded this species from the lower Sefidroud River,
Anzali wetland and from middle Aras River. $H$. leucisculus found in rivers, lakes, small ponds and swamps but there is a little finding about its habitat requirements (Coad, 2013). H. leucisculus is an edible fish and is conserved in China but it is more important because it compete with innate species for food and predation on fish eggs and young (Holčík and Razavi, 1992). The $H$. leucisculus can easily modify their food habit as conditions warrant (Holčík and 
Razavi, 1992). For the adequate management length-weight and length-length relationships, condition factor and growth are important tools for any fish species (King, 2007; Ndome et al., 2012). Lengthweight importance is clear in estimating the average weight at a given length group (Beyer, 1987), and in assessing the relative wellbeing of a fish population (Bolger and Connoly, 1989), and are useful for between region comparisons of like histories of a specific species (Wootton, 1990). For comparison of growth studies, length-length relationship is important factor (Moutopoulos and Stergiou, 2002). The results of condition factor can be used to compares the wellbeing of a fish and is based on the theory that heavier fish of a given length are in better condition (Bagenal and Tesch, 1978), it is used as an index of growth and feeding intensity (Fagade, 1979). Condition factor is decreases with increase in length (Bakare, 1970; Fagade, 1979), and also influences the reproductive cycle in fish (Welcome, 1979). The length-weight relations of some species recently have been studied in Iran and other localities (Barrientos-Medina et al., 2013; Mousavi-Sabet et al., 2013; Moutopoulos et al., 2013; Qiang et al., 2013). The available information about fish population biology including length-weight relationship in Iran is restricted to some information on commercially important marine and freshwater fishes (Hosseini, 2002; Shokri et al., 2005; Esmaeili, 2006; Raeisi et al., 2011; Mousavi-Sabet et al., 2013). This study presents information about length-weight and length-length relationships, relative condition factor and Fulton's condition factor for $H$. leucisculus in Sefidroud River, in southwestern of the Caspian Sea basin.

\section{Materials and methods}

The sampling was carried out in Sefidroud River $\left(37^{\circ} 15.46^{\prime} \mathrm{N}, 049^{\circ} 5.598^{\prime} \mathrm{E}\right)$. The river is located in the north of Iran, in southwestern of the Caspian Sea basin (Fig. 1). Sampling was done from March 2012 to February 2013. The fish were caught with traditional fishing gears. All specimens were fixed and preserved in 8\% formaldehyde solution and transferred to the ichthyology laboratory of department of fisheries sciences, faculty of natural resources, the University of Guilan. For each specimen total length (TL), fork length (FL) and standard length (SL) were measured by using measuring board nearest $1 \mathrm{~mm}$, body weight $(\mathrm{g})$ was taken on a digital balance with $0.01 \mathrm{~g}$ accuracy. And the sex was assigned by examining the gonads.

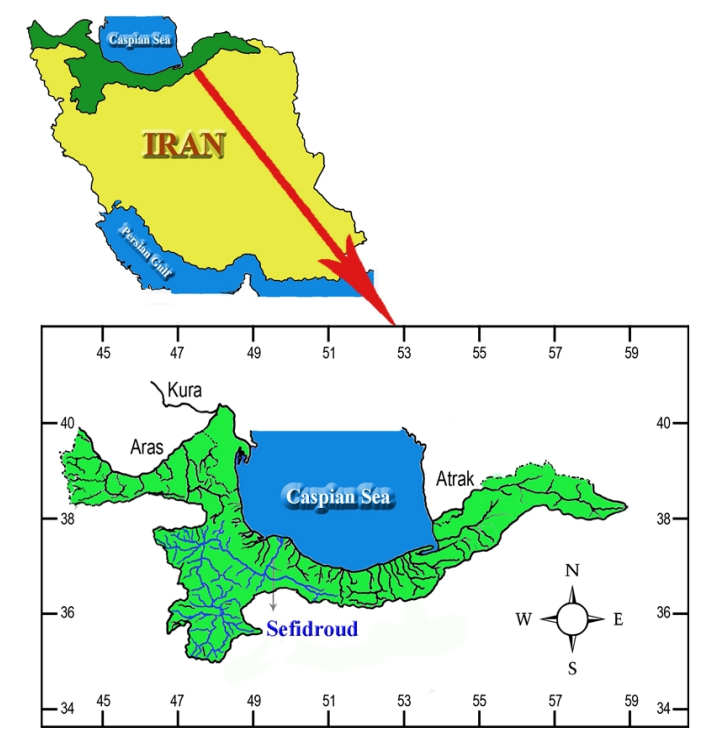

Figure 1. Map of Iranian part of the southern Caspian Sea basin showing some of the most important river system: Aras, Kura, Atrak and Sefidrud (the study area) rivers.

The length-weight relationship was estimated by using the equation, $\mathrm{W}=\mathrm{aL}^{\mathrm{b}}$ 
(Froese, 2006). Where $\mathrm{W}$ is the whole body weight $(\mathrm{g}), \mathrm{L}$ is the total length $(\mathrm{cm})$, a is the intercept of the regression and $b$ is the regression coefficient (slope). Values of the exponent $\mathrm{b}$ provide information on fish growth. When $b=3$, increase in weight is isometric. When the value of $b$ is other than 3 , weight increase is allometric (positive if $b>3$, negative if $b<3$ ). This parameters $(a, b)$ are important in stock assessment studies (Can et al., 2002; Moutopoulos and Stergiou, 2002). The parameters $a$ and $b$ of the length-weight relationships were estimated by the least-squares method based on logarithms: $\log (\mathrm{W})=\log (\mathrm{a})+\mathrm{b} \log$ (TL).

Moreover relationships among the, TL-FL, FL-SL, and SL-TL were calculated by linear regressions. Also the relative condition factor $\left(\mathrm{K}_{\mathrm{rel}}\right)$ and Fulton's condition factors $(\mathrm{K})$ were calculated for each individual fish according to the equation (Le cren, 1951; Froese, 2006): $\mathrm{K}_{\text {rel }}$ $=\mathrm{w} / \mathrm{al}^{\mathrm{b}}, \mathrm{K}=100 \mathrm{w} / \mathrm{l}^{3}$. Where $\mathrm{W}$ is the whole body weight $(\mathrm{g}), \mathrm{L}$ is the total length $(\mathrm{cm})$, and $a$ and $b$ are the parameters of lengthweight relationship.

\section{Results and discussion}

A total of 235 specimens of $H$. leucisculus were collected from Sefidroud River (SW of the Caspian Sea basin). The sample size (n), length range, parameters $a$ and $b$ of the length weight relationship, and the determined coefficient $\left(\mathrm{r}^{2}\right)$ are given monthly, also length weight relationships were presented for males, females and malefemales in table 1 . The highest mean of total length $(15.61 \mathrm{~cm})$ value of the samples was in August whereas the lowest mean of total length $(12.95 \mathrm{~cm})$ value was in April. The mean of total length values for males, females and male-females were 14.04,
14.20 and 14.30 respectively and shown in table 1. Determined coefficient $\left(r^{2}\right)$ values for males, females and male-females were $0.925,0.872$ and 0.868 , respectively.

In the present study, the obtained ' $b$ ' values for length-weight relationship were lower than 3, i.e., 2.549, 2.680 and 2.465 for males, females and male-females respectively which indicated that the growth is negative allometric in H. leucisculus. This is agreed with obtained data for Gudusia godanahiae from Nepal (Subba et al., 2009). The results of the present study are not in agreement with reports by Gavrenkov and Ivankov (1976), Subba and Adhikaree (2011) and Moradinasab et al. (2012). But Ye et al. (2007) showed also negative allometric growth for this species. The variation of $b$ values is determined by primarily on the shape and fatness of the species, various factors may be responsible for the differences in parameters of the length-weight relationships among seasons, sex and time of year and stages of maturity (Sparre, 1992).

Length-length relationships and the coefficient of determination $\left(\mathrm{r}^{2}\right)$ are given in table 2. All LLRs (Tab. 2) were highly significant $(\mathrm{P}<0.001)$, with all coefficient of determination values being $>0.968$. The values of $a, b$ and $r^{2}$ were $0.409,0.927$ and 0.93 respectively for length-length relationship of $H$. leucisculus from the Anzali wetland (Moradinasab et al., 2012).

The monthly Fulton's condition factor $(\mathrm{K})$ was ranged from 0.745 to 0.996 and also in males, females and male-females Fulton's condition factor $(\mathrm{k})$ were 0.842 , 0.922 and 0.843 respectively that shown in table 3 . The lowest and highest mean of $\mathrm{K}$ were found in August (K 0.745) and June (K 0.996) respectively. Monthly relative condition factor $\left(\mathrm{K}_{\mathrm{rel}}\right)$ was ranged from 
H. Mousavi-Sabet, A. Habibi and O. Bagherpur / Our Nature (2013), 11(1): 25-30

Table 1. Descriptive statistics and length-weight parameters for H. leucisculus in Sefidroud River, SW of the Caspian Sea basin.

\begin{tabular}{|c|c|c|c|c|c|c|c|c|c|}
\hline \multirow{2}{*}{ Month } & \multirow{2}{*}{ Sex } & \multirow{2}{*}{ Length } & \multirow{2}{*}{$\mathbf{N}$} & \multicolumn{3}{|c|}{ Length characteristics (cm) } & \multicolumn{3}{|c|}{ Parameters of relationship } \\
\hline & & & & Min. & Max. & Mean \pm SD & $\mathbf{A}$ & B & $\mathbf{R}^{2}$ \\
\hline January & unsexed & TL & 13 & 10.40 & 16.40 & $14.63 \pm 1.60$ & 0.183 & 1.767 & 0.882 \\
\hline February & unsexed & TL & 20 & 12.90 & 17.80 & $15.12 \pm 1.56$ & 0.068 & 2.556 & 0.922 \\
\hline March & unsexed & TL & 23 & 12.10 & 15.90 & $14.20 \pm 1.05$ & 0.142 & 1.955 & 0.736 \\
\hline April & unsexed & TL & 26 & 9.30 & 15.20 & $12.95 \pm 1.53$ & 0.060 & 2.691 & 0.950 \\
\hline May & unsexed & TL & 23 & 9.60 & 16.60 & $13.34 \pm 2.30$ & 0.077 & 2.530 & 0.947 \\
\hline June & unsexed & TL & 11 & 12.30 & 18.10 & $14.90 \pm 1.62$ & 0.113 & 2.205 & 0.992 \\
\hline July & unsexed & TL & 25 & 13.33 & 18.05 & $15.69 \pm 1.39$ & 0.109 & 2.306 & 0.985 \\
\hline August & unsexed & TL & 21 & 13.30 & 18.00 & $15.61 \pm 1.36$ & 0.105 & 2.224 & 0.809 \\
\hline September & unsexed & TL & 33 & 9.10 & 14.80 & $12.62 \pm 1.81$ & 0.083 & 2.386 & 0.750 \\
\hline October & unsexed & TL & 17 & 9.30 & 17.60 & $14.74 \pm 2.02$ & 0.079 & 2.452 & 0.982 \\
\hline November & unsexed & TL & 27 & 12.60 & 17.30 & $14.93 \pm 1.11$ & 0.240 & 1.546 & 0.515 \\
\hline December & unsexed & TL & 8 & 12.30 & 14.90 & $13.75 \pm 0.83$ & 0.092 & 2.340 & 0.835 \\
\hline \multirow[t]{3}{*}{ Total } & unsexed & TL & 235 & 9.10 & 18.10 & $14.30 \pm 1.71$ & 0.079 & 2.465 & 0.868 \\
\hline & Male & TL & 99 & 9.30 & 16.90 & $14.04 \pm 0.382$ & 0.074 & 2.549 & 0.925 \\
\hline & Female & $\mathrm{TL}$ & 136 & 9.10 & 18.10 & $14.20 \pm 0.274$ & 0.061 & 2.680 & 0.872 \\
\hline
\end{tabular}

$\left(\mathrm{N}=\right.$ Number of specimens, $\mathrm{A}$ and $\mathrm{B}=$ Parameters of the $\mathrm{L}-\mathrm{W}$ relation, $\mathrm{R}^{2}=$ Coefficient of determination $)$

Table 2. Length-length relationships among total length (TL), fork length (FL) and standard length (SL) of $H$. leucisculus in Sefidroud River, SW of the Caspian Sea basin.

\begin{tabular}{lllccc}
\hline \multirow{2}{*}{ Sex } & \multirow{2}{*}{ N } & \multirow{2}{*}{ Equation } & \multicolumn{3}{c}{ Regression Parameters } \\
\cline { 3 - 5 } Male & 99 & $\mathrm{TL}=\mathrm{a}+\mathrm{bFL}$ & 0.405 & $\mathbf{B}$ & $\mathbf{R}^{\mathbf{2}}$ \\
& & $\mathrm{FL}=\mathrm{a}+\mathrm{bSL}$ & 0.335 & 0.873 & 0.983 \\
& & $\mathrm{SL}=\mathrm{a}+\mathrm{bTL}$ & 0.451 & 0.08 & 0.982 \\
& & $\mathrm{TL}=\mathrm{a}+\mathrm{bFL}$ & 0.389 & 0.907 & 0.980 \\
\hline Female & \multirow{2}{*}{136} & $\mathrm{FL}=\mathrm{a}+\mathrm{bSL}$ & 0.371 & 0.958 & 0.983 \\
& & $\mathrm{SL}=\mathrm{a}+\mathrm{bTL}$ & 0.437 & 0.895 & 0.985 \\
& & $\mathrm{FL}=\mathrm{a}+\mathrm{bTL}$ & 0.394 & 0.896 & 0.968 \\
\hline Total & 235 & $\mathrm{FL}=\mathrm{a}+\mathrm{bSL}$ & 0.357 & 0.993 & 0.971 \\
& & $\mathrm{SL}=\mathrm{a}+\mathrm{bTL}$ & 0.443 & 0.883 & 0.981 \\
& & & & & 0.973 \\
\hline
\end{tabular}

$\left(\mathrm{N}=\right.$ Number of specimens, $\mathrm{A}$ and $\mathrm{B}=$ Parameters of the $\mathrm{L}-\mathrm{L}$ relations, $\mathrm{R}^{2}=$ Coefficient of determination)

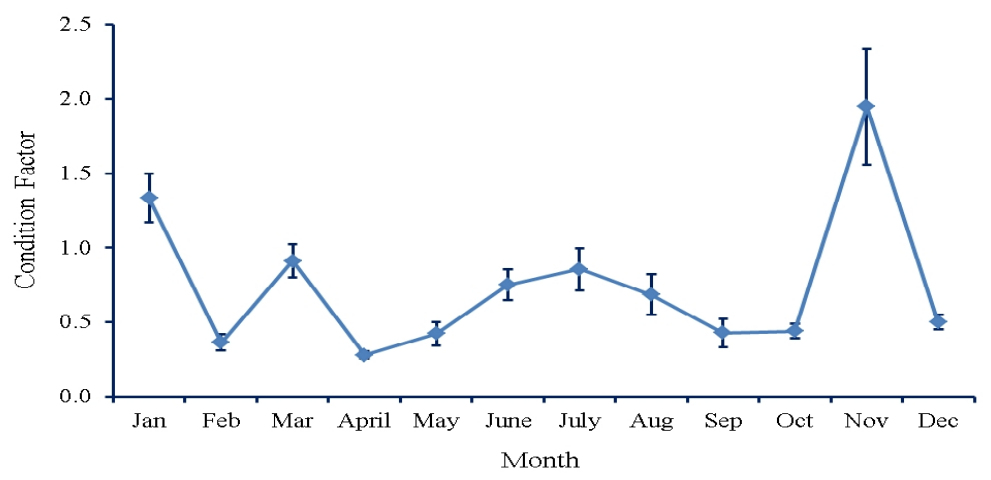

Figure 2. Variation of condition factors (mean $\pm \mathrm{SE}$ ) of H. leucisculus in Sefidroud River, SW of the Caspian Sea basin. 
0.281 to 1.947 which were $0.710,0.622$ and 0.743 for male, female and male-females respectively (Fig. 2). The lowest $\left(\mathrm{K}_{\text {rel }} 0.281\right)$ and highest $\left(\mathrm{K}_{\text {rel }} 1.947\right)$ mean of $\mathrm{K}_{\text {rel }}$ were found in April and November, respectively. Moradinasab et al. (2012) examined K $(0.80$ $\pm 0.05)$ and $\mathrm{K}_{\text {rall }}(1.00 \pm 0.07)$ values for male-females of $H$. leucisculus in the Anzali wetland. In studies of population dynamics high condition factor values indicates favorable environmental conditions and low values indicate less favorable environmental conditions (Blackwell et al., 2000). A number of factors such as sex, seasons, environmental conditions, stress, preservation, maturity, availability of food also affect the condition of fish.

In conclusion, this paper has provided basic data on the LWR, LLR, $\mathrm{K}$ and $\mathrm{K}_{\text {rel }}$ that would be beneficial for fishery biologist's managers to impose suitable regulations for sustainable fishery management in the Sefidroud River.

Table 3. Relative condition factor $\left(\mathrm{K}_{\mathrm{rel}}\right)$ and Fulton's condition factor $(\mathrm{K})$ for $H$. leucisculus in Sefidroud River, SW of the Caspian Sea basin.

\begin{tabular}{lcc}
\hline Month & Sex & Fulton's condition factor (K) \\
\hline January & Unsexed & 0.901 \\
February & Unsexed & 0.750 \\
March & Unsexed & 0.811 \\
\hline April & Unsexed & 0.775 \\
May & Unsexed & 0.975 \\
June & Unsexed & 0.996 \\
July & Unsexed & 0.686 \\
August & Unsexed & 0.745 \\
September & Unsexed & 0.763 \\
October & Unsexed & 0.806 \\
November & Unsexed & 0.921 \\
December & Unsexed & 0.816 \\
\hline Total & Unsexed & 0.843 \\
& Male & 0.922 \\
& Female & 0.842 \\
\hline
\end{tabular}

\section{References}

Abdoli, A. 2000. The inland water fishes of Iran. Iranian Museum of Nature and Wildlife, Tehran. $378 \mathrm{p}$.

Bagenal, T.B. and A.T. Tesch 1978. Conditions and growth patterns in fresh water habitats. Blackwell Scientific Publications, Oxford.

Bakare, O. 1970. Bottom deposits as food of inland fresh water fish. In Kainji, A Nigerian manmade Lake. Kanyi Lake studies (Ed. S.A. Visser.), Vol. 1. Ecology Published for the Nigerian Institute.

Barrientos-Medina, R.C., S. Avilés-Torres and J.A. Navarro-Alberto 2013. Length-weight relations of eight fish species from a small Caribbean coastal lagoon, Mexico. Act. Ichthyol. Piscat. 43(1): 7174.

Beyer, J.E. 1987. On length-weight relationship computing the mean weight of the fish of a given length class. Fishbyte. 5(1): 11-13.

Blackwell, B.G., M.L. Brown and D.W. Willis 2000 Relative weight (Wr) status and current use in fisheries assessment and management. Rev. Fish. Sci. 8(1): 1-44.

Bolger, T. and P.L. Connoly 1989. The selection indices for the measurement and analysis of fish condition. J. Fish Biol. 17(3): 1-182.

Can, M.F., N. Basusta and M. Cekic 2002. Weightlength relationships for selected fish species of the small-scale fisheries of the south coast of Iskenderun Bay. Turk. J. Vet. Anim. Sci. 26: 11811183.

Coad, B.W. 2013. Freshwater fishes of Iran. Available at http://www.briancoad.com (accessed on 15 May, 2013).

Esmaeili, A. 2006. Technical efficiency analysis for the Iranian fishery in the Persian Gulf. J. Mar. Sci. 63(9): 1759-1764.

Esmaeili, H.R., A. Gholamifar and J. Freyhof 2011. Ichthyofauna of Zarivar Lake (Iran) with the first records of Hemiculter leucisculus and Alburnus hohenackeri in the Tigris drainage. Electro. $J$. Ichth. 7(1): 1-6.

Fagade, S.O. 1979. Observation of the biology of two species of Tilapia from the Lagos lagoon Nigeria. Bull. Inst. Fond Afr.Nore (ser. A) 41: 627-658.

Froese, R. 2006. Cube law, condition factor and length-weight relationships: history, meta-analysis and recommendations. Appl. Ichthyol. 22(4): 241253.

Gavrenkov, Y.I. and V.N. Ivankov 1976. Morpho- 
biological analysis of Ussuri sharpbelly and sharpbelly of Khanka lake. Biology of the far east fishes, Collected papers. Vladivostok, Far Eastern State University. Pp. 64-69.

Holčík, J. and V.A. Razavi 1992. On some new or little known freshwater fishes from the Iranian coast of Caspian Sea. Folia Zool. 41(3): 271280.

Hosseini, S.A. 2002. Some biological aspects of Thunnus albacres and Katsuwonus pelamis in Oman Sea (Sistan-o-Balochestan Province). Iran. J. Fish. Sci. 11: 35-62.

King, M. 2007. Fisheries biology, assessment and management. Wiley-Blackwell. 400p.

Le cren, E.D. 1951. The length-weight relationships and seasonal cycle in gonad weight and condition in the perch (Perca fluviatilis). $J$. Anim. Ecol. 20(2): 201-219.

Moradinasab, G., M. Daliri, R. Ghorbani, S.Y. Paighambari and R. Davoodi 2012. Length-weight and length-length relationships, Relative condition factor and Fulton's condition factor of Five Cyprinid species in Anzali wetland, southwest of the Caspian Sea. Caspian J. Env. Sci. 10(1): 2531.

Mousavi-Sabet, H., S. Abdollahpour, A. SalehiFarsani, S. Vatandoust, H.F. Langroudi, H.R. Jamalzade and A. Nasrollahzadeh 2013. Lengthweight and length-length relationships and condition factor of Alburnus mossulensis from the Persian Gulf basin. AACL Bioflux 6(4): 297-302.

Moutopoulos, D.K. and K.I. Stergiou 2002. Lengthweight and length-length relationships of fish species from the Aegean Sea (Greece). J. Appl. Ichtyol. 18(3): 200-203.

Moutopoulos, D.K., A. Ramfos, A. Mouka and G. Katselis 2013. Length-weight relations of 34 fish species caught by small-scale fishery in Korinthiakos Gulf (Central Greece). Act. Ichthyol. Piscat. 43(1): 57-64.

Ndome, C.B., A.O. Eteng and A.P. Ekanem 2012. Length-weight relationship and condition factor of the smoothmouth marine catfish (Carlarius heudelotii) in the gulf of Guinea, Niger delta, Nigeria. AACL Bioflux. 5(3): 163-167.

Patimar, R., A. Abdoli and B.H. Kiabi 2008 Biological characteristics of the introduced Sawbelly, Hemiculter leucisculus (Basilewski, 1855), in three wetlands of northern Iran: AlmaGol, Adji-Gol and Ala-Gol. J. Appl. Ichtyol. 24(5): 617-620.

Qiang, L.I., X.U. Ruilin and H.U.A.N.G. Jianrong 2013. Length-weight relations for 20 fish species from the Pearl River, China. Act. Ichthyol. Piscat. 43(1): $65-69$.

Raeisi, H., M. Daliri, S.Y. Paighambari, M.J. Shabani, M. Bibak and R. Davoodi 2011. Length-weight relationships, condition factors and relative weight of five fish species of Bushehr waters, Northern Persian Gulf. African Journal of Biotechnology 10: 19181-19186

Shokri, M.R., S.M.R. Fatemi and M.P. Crosby 2005. The status of butterfly fishes (Chaetodontidae) in the northern Persian Gulf. Mar. Freshw. Ecosyst. 15: 91-99.

Sparre, P. 1992. Introduction to tropical fish stock assessment. Part I Manual. FAO Fisheries Technical Paper 306/1. Rev 1. Rome. 376p.

Subba, B.R., R.P. Bhagat and S. Adhikaree 2009. Studies on length-weight and length-length relationships of a freshwater fish Gadusia godanahiae from Biratnagar, Nepal. Our Nature 7: 218-221.

Subba, S., and S. Adhikaree 2011. Studies on lengthweight and length-length relationships of a cold water fish Neolissochilus hexagonolepis (McClelland) from Tamor River, Nepal. Our Nature 9: 168-172.

Welcome, R.L. 1979. Fisheries ecology of flood plain rivers. Longman Press, London. 317p.

Wootton, R.J. 1990. Ecology of teleost fishes. Chapman and Hall, London. 404p.

Ye, S., Z. Li, G. Feng and W. Cao 2007. Lengthweight relationships for thirty fish species in lake Niushan, a shallow macrophytic Yangtze Lake in China. As. Fish. Sci. 20(2): 217-226. 